\title{
Review on Status and Trends in Taxation of Foreign Economic Operations in Ukraine
}

\author{
Natalie Yuriivna Shevchenko ${ }^{1}$, Shulga Ievgenii Viktorovych ${ }^{2}$ \\ ${ }^{1}$ Department of Finance, National University of Life and Environmental Sciences of Ukraine, Kyiv, Ukraine \\ ${ }^{2}$ Department of International and Comparative Law, National University of Life and Environmental Science of Ukraine, Kyiv, Ukraine
}

Email address:

200582_@ukr.net (N. Y. Shevchenko),evshulga2013@gmail.com (S. I. Viktorovych)

\section{To cite this article:}

Natalie Yuriivna Shevchenko, Shulga Ievgenii Viktorovych. Review on Status and Trends in Taxation of Foreign Economic Operations in Ukraine. International Journal of Economics, Finance and Management Sciences. Special Issue: Taxation of Foreign Economic Operations with Agricultural Products. Vol. 7, No. 4, 2019, pp. 103-106. doi: 10.11648/j.ijefm.20190704.12

Received: July 3, 2019; Accepted: August 20, 2019; Published: September 6, 2019

\begin{abstract}
Taxation of foreign economic operations is carried out by applying tariff and non-tariff regulatory methods and is based on the use of tax policy instruments - customs duty, excise duty and VAT. Having defined its foreign economic and tax policy, the state determines the direction for development, as well as the strategy and tactics to achieve the goal through foreign economic operations. Based on the generalization of theoretical foundations, it is determined that foreign economic operations are a type of foreign economic activity aimed at implementing a trade agreement between countries. The customs duty is of the utmost importance in taxation. By economic nature, it is an integral part of the taxation of foreign economic operations. During the research process the economic importance of customs duty was deepened and determined that, unlike other indirect taxes, which are primarily aimed at fiscal purposes, customs duty is a tool for financial regulation of the country's economy, namely it stimulates inefficient domestic production and perform other functions for foreign trade development. The theoretical, methodological and practical provisions concerning taxation of foreign economic operations with agricultural products and assessment of its functioning efficiency in conditions of Ukrainian integration into the EU are studied. A comprehensive approach to the implementation of the regulation in foreign economic operations with agricultural products is proposed. The directions to improve taxation of foreign economic operations are substantiated.
\end{abstract}

Keywords: Indirect Taxation, Customs Duty, Foreign Economic Activity and Operations, Agricultural Products, Customs Tariff Regulations, EU

\section{Introduction}

Effective regulation of the country's economy in conditions of European integration requires improvement in taxation of foreign economic operations. From the adaptation to its requirements, the efficiency level of state regulation in foreign economic operations will depend. The necessity for a comprehensive and systematic solution to these problems conditioned the relevance of the research topic that is confirmed by the implementation of recommendations developed by the author into the science and practice.

Different aspects of functioning the taxation of foreign economic operations are disclosed in the research papers of Ukrainian scientists: V. Andrushchenko [1], I. Burakovskyi [2], K. Choi [3], O. Kireev [4], O. Labenko [5], P. Laiko [6], M. Melnyk [7], R. Sabluk [8], O. Shpichak [9], and others.
The theoretical basis for understanding the problems of taxation of foreign economic operations is embedded in the scientific works of such famous foreign economists as $\mathrm{P}$. Samuelson [10] and other researchers.

\section{Main Results of the Studies}

\subsection{Theoretical Foundations for Taxation of Foreign Economic Operations}

Every country implements an integrated approach for regulating foreign economic operations, which manifests itself in the use of various regulatory tools that interact and complement each other.

The investigation have shown that the relationship of foreign economic and tax policy of the state is carried out by 
applying tariff and non-tariff regulatory methods and is based on the use of tax policy instruments - customs duty, excise duty and value-added tax (VAT).

Exceptional value in taxation has customs duty that is imposed on goods crossing the customs border in the process of foreign economic operations. By the economic essence, it is an integral part of taxation of foreign economic operations, but unlike other indirect taxes, which are primarily aimed at fiscal goals, the customs duty is an instrument for financial regulation of the country's economy, in particular foreign trade. Understanding the economic essence of customs duties allowed establishing that customs clearance fee has the features and characteristics of the customs duty by which it might be interpreted as a specific and compulsory payment of foreign commodity producers for access to domestic markets.

It is established that effective taxation of foreign economic operations with agricultural products depends on the clear interaction of all elements in the tax mechanism, in particular its methods, tools and levers; on the complex and effective interaction of its subjects and objects, endogenous and exogenous factors; and the systematization of the relevant factors allows adapting it to the peculiarities of foreign economic activity of the state.

Evolution in the development of taxation of foreign economic operations testifies about a continual search for its optimality. The solution to this problem was ambiguous. However, as the economic history shows, taxation of foreign economic operations entirely depends on the country's foreign trade regime, which determines the protection level for the domestic market.

Thus, based on the generalization of theoretical foundations, the main tools for state regulation are foreign economic operations and taxes such as excise duty and VAT, which are classified as internal taxes on operations with supply of goods and services, and customs duty - as a tax on international trade and foreign operations. In this context, it is proposed to improve the classification of taxes on foreign economic operations, which includes internal and external factors, namely, it is proposed to unite them and divide into two taxes categories on foreign economic operations: taxes levied on the taxation of domestic operations and taxes levied on foreign economic operations.

\subsection{Assessment of Status and Trends in Taxation of Foreign Economic Operations with Agricultural Products}

On the example of grain crops, the dynamics of tax revenues from foreign economic operations with agricultural products was analyzed, and the influence of the main factors on the size of tax revenues such as price, import customs duty rate, import volume and the national currency were analyzed.

Ukraine's foreign economic activity is aimed at joining to the global agricultural market and is a part of the products economic circulation between countries.

The potential of the agricultural sector and natural climatic conditions of Ukraine allow it to function as a powerful exporter of agricultural products and products of its processing.

The analysis of Ukraine's foreign trade policy during 2000-2018 shows that the export of agricultural products has substantial growth rates and increased almost by 6 times. The greatest share in agricultural export has grain, the export volume of which for the analyzed period also increased.

It should be noted that foreign economic operations are a significant factor affecting the state tax base. The main task of the state in the field of foreign trade is to provide the effective functioning of taxation of foreign economic activity.

The analysis of the fiscal efficiency of indirect taxes in the structure of taxation of foreign economic operations showed an increasing role of VAT and excise duty, and a decreasing role of customs duty.

Besides that, the volume of tax revenues depends on foreign economic operations and economic development of Ukraine. In the conditions of economic instability, the imbalance of these components may lead to a violation of the relationship between fiscal and foreign economic policy of a state, and to reduce its efficiency.

It was investigated that the stability of tax revenues is determined mainly by the level of internal prices, by the export and import operations structure, and other factors.

Confirmation of the obtained conclusions is the change in tax revenues due to hryvnia exchange rate drop in recent years, which was accompanied by an increase in the defense potential even in conditions of a minimal customs duty rate, an increase in the volume of products import and prices in compare with previous years.

It was established that the problem of untimely VAT refund continues to be one of the key issues that negatively affects the activity of grain crop exporters, and in particular, leads to a decrease in the grain production and export. According to the results of the conducted research, it is proved that untimely VAT refund reduces the production volume of this product at the level of 24-34 thousand tons annually, and therefore reduces the grain export $[11,12]$.

\subsection{The Main Directions to Improve Taxation of Foreign Economic Operations with Agricultural Products}

The directions for adaptation of customs tariff regulation of foreign economic operations in the context of European integration and for increasing fiscal importance of taxation of foreign economic operations are substantiated.

Development of foreign economic operations with agricultural products cannot be fulfilled without its effective customs tariff regulation. In order to balance the customs duty function when setting import duty rates, achievements of more homogeneous tariff structure and proportional removal of tariff peaks by the tariff escalation method are confirmed, which contributed to the promotion of domestic products into foreign markets [13].

Implementation of such a method is effective in order to influence the structure of the foreign trade balance, ensuring the control of export and import flows of agricultural products, optimization of customs tariffs and increase of competitiveness. 
The research revealed that the main criteria for the formation of an effective mechanism for customs tariff regulation of foreign economic activity, in particular grain imports, should include the domestic market saturation, the efficiency of foreign economic operations with grain products and the forecast of its volumes, etc. Based on these criteria, it is proposed to use the developed customs tariff tools. At the same time, yield forecasting and balance of food resources determines the potential volumes of agri-food products export and the necessary its import volumes in order to protect the domestic products market or to achieve balance. The effectiveness of foreign economic operations provides an opportunity to the exporter to assess the feasibility of one or another operation that he intends to carry out $[14,15]$.

To resolve the problem of untimely VAT refund to grain exporters, a new mechanism has been proposed, which provides for compensation of unreturned sums of VAT from the state by agricultural equipment under leasing on concessional terms. Based on this mechanism, the amount of monthly lease payments, which the state will pay for the use of machinery by exporters within the amount of debt, is calculated. This mechanism will contribute to resolving the urgent problems of untimely VAT refunds.

It is established that the export volumes of grain crops will exceed the imports volume that means that Ukraine will maintain a positive trade balance in this sector in the coming years.

\section{Conclusion}

According to the research results, it revealed that the validity of efficient management of foreign economic activity depends on the complex and effective interaction of all components in foreign economic and fiscal policy in a descriptive model, the implementation of which will provide an increase in the efficiency of foreign economic activity and economic growth in the industry.

The status of taxation of foreign economic operations with agricultural products is evaluated, and it is determined that tax revenues from it form the prevailing share of total revenues from indirect taxes in Ukraine. At the same time, there is a tendency to gradually increase in the share of excise duty and VAT in the total tax payments, and decrease in the fiscal role of customs duty due to the introduction of reduced rate for products.

The current system of customs tariff regulation in Ukraine does not meet the generally accepted world practice criteria for European integration, and therefore requires to be improved. This causes the further use of tariff escalation based on the optimization of customs tariffs level depending on the growth in the products processing degree and ensuring its differentiation within the framework of general agreements.

The implementation of the proposed mechanism for regulation of foreign economic operations with grain crops based on the criteria of the domestic market saturation, determination of the efficiency for foreign economic operations with grain products and the use of the developed necessary customs tools will contribute to increase in economic efficiency level of foreign economic operations.

\section{References}

[1] Andrushchenko, V. L. (2008). Podatkova derzhava: genezis, koncepciya, evolyuciya [Tax State: Genesis, Concept, Evolution]. The World of Finance, 3 (16), 7-15.

[2] Burakovskyi, I. (2004). Vstup Ukraini do SOT: yak pravilno ociniti naslidki [Ukraine's accession to the WTO: how to properly assess the consequences]. Economic Journal - XXI, 7-8.

[3] Choi, K., \& Lim, S. (2019). A reappraisal of strategic trade policies with the endogenous mode of competition under vertical structures. Journal of international trade \& economic development, 28, 11-29. doi: https://doi.org/10.1080/09638199.2018.1482948

[4] Kireev, A. (2002). International Economics. Part I. International microeconomics: movement of goods and factors of production [Mezhdunarodnaya ekonomika. Part I. Mezhdunarodnaya mikroekonomika: dvizhenie tovarov i faktorov proizvodstva]. Moscow: International Attitude.

[5] Labenko, O. M., \& Shevchenko, N. Yu. (2015). Assessment of the system of tax regulation of agricultural commodity producers in Ukraine [Otsinka systemy podatkovoho rehuliuvannia silskohospodarskykh tovarovyrobnykiv Ukrainy]. Scientific works of Poltava State Agrarian Academy, 360.

[6] Laiko, P. A., \& Osadchyi, S. O. (2005). Indirect taxation of agricultural producers [Nepryame opodatkuvannya silskogospodarskix virobniki]. Kyiv: Knowledge.

[7] Melnyk, M., Korcelli-Olejniczak, E., \& Chorna, N. (2018). Development of regional IT clusters in Ukraine: institutional and investment dimensions. Economic Annals-XXI, 173, 910 .

[8] Sabluk, R. P., \& Kovalenko, O. V. (2009). Suchasni tendenciï svitovoï torgivli zernom [Current trends in world grain trade]. APK economy, 19, 84-88.

[9] Shpichak, O. O. (2004). Opodatkuvannia eksportnoimportnykh operatsii z produktsiieiu roslynnytstva [Taxation of export-import operations with crop production]. Kyiv: NNC IAE.

[10] Samuelson, P. A. (1954). The transfer problem and transport costs: the analysis of the effects of trade impediments. Economic Journal, 64, 265-280.

[11] Shevchenko, N. Yu. (2015). Teoretyko-metodychni aspekty opodatkuvannia zovnishnoekonomichnykh operatsii $\mathrm{Z}$ produktsiieiu ahropromyslovoho vyrobnytstva [Theoretical and methodical aspects of taxation of foreign economic operations with products of agricultural production]. Scientific Bulletin of NULES of Ukraine, 222, 287-290.

[12] Shevchenko, N. Yu. (2015). Osnovni chynnyky vplyvu na podatkovi nadkhodzhennia vid zovnishnoekonomichnykh operatsii z produktsiieiu ahropromyslovoho vyrobnytstva [The main factors influencing tax revenues from foreign economic operations with products of agro-industrial production]. Scientific Bulletin of NULES of Ukraine, 231. 
[13] Shulga, I. (2017). Features of forcasting administrative delicacy. Visegrad Journal on Human Rights, 4 (2), 190-194.

[14] The Common Agricultural Policy Explained. European Commission Directorate-General for Agriculture and Rural Development. Retrieved from http://ec.europa.eu/agriculture/publi/capexplained/cap_en.pdf
[15] European commission.
http://ec.europa.eu/index_en.htm

from 